\title{
Gastric Leiomyosarcoma Associated with Hypoglycemia in Dog-A Case Report
}

\author{
Jéssica Ragazzi Calesso', Mariah Castelani Aires De Araujo², Thalita Evani Silva De Oliveira², \\ Izabelle Galiardo Garcia ${ }^{2}$, Michelle Campano De Souza², Giovana Wingeter Di Santis², \\ Carmen Lúcia Scortecci Hilst ${ }^{2}$, Patrícia Mendes Pereira², Mauro José Lahm Cardoso ${ }^{2 *}$
}

\author{
${ }^{1}$ College of Veterinary Medicine, Federal University of Minas Gerais (UFMG), Belo Horizonte, MG, Brazil \\ ${ }^{2}$ Department of Veterinary Clinics, State University of Londrina (UEL), Londrina, PR, Brazil \\ Email: *maurolahm@gmail.com
}

How to cite this paper: Calesso, J.R., De Araujo, M.C.A., De Oliveira, T.E.S., Garcia, I.G., De Souza, M.C., Di Santis, G.W., Hilst, C.L.S., Pereira, P.M. and Cardoso, M.J.L. (2019) Gastric Leiomyosarcoma Associated with Hypoglycemia in Dog-A Case Report. Open Journal of Veterinary Medicine, 9, 101-108.

https://doi.org/10.4236/ojvm.2019.98009

Received: June 19, 2019

Accepted: August 5, 2019

Published: August 8, 2019

Copyright $\odot 2019$ by author(s) and Scientific Research Publishing Inc. This work is licensed under the Creative Commons Attribution International License (CC BY 4.0).

http://creativecommons.org/licenses/by/4.0/

\begin{abstract}
Neoplasms of the digestive system are uncommon in dogs, and may be of epithelial, neuroendocrine, hematopoietic and mesenchymal origin. The leiomyosarcoma is a tumor of mesenchymal origin of smooth, malignant, slow-growing muscles. Paraneoplastic syndromes can affect different systems, being the most commonly found: hypercalcemia, hypoglycemia, cachexia and anemia. There are rare cases of mesenchymal tumors of the gastrointestinal tract in dogs that result in hypoglycaemia with clinical signs. The objective of this study is to report a case of gastric leiomyosarcoma associated with clinical hypoglycemia. The patient had neurological signs such as ataxia and seizures associated with hypoglycemia, which did not recur after surgical excision of the tumor. The definitive diagnosis was based on the histopathological and immunohistochemical examination of the tumor.
\end{abstract}

\section{Keywords}

Canine, Glycemia, Neoplasia, Paraneoplastic Syndrome

\section{Introduction}

Gastric neoplasms, such as leiomyosarcoma, are uncommon in dogs [1] [2] [3] and occur in less than $1 \%$ of all tumors of the species [3] [4]. The highest occurrence age is 9 to 12 years [5], with a higher risk of male dogs from large breeds [3]. The leiomyosarcoma is a malignant, slow-growing, locally invasive tumor originating from the smooth muscle, where metastasis occurs slowly [5] [6] [7]. Clinical signs depend on the nature and location of the tumor, which may cause obstruction of the gastric flow, ulceration and result in melena, anemia and le- 
thargy [1] [8].

Hypoglycemia (serum glucose lower than $65 \mathrm{mg} / \mathrm{dL}$ ), associated with oncology patients, has as its main cause insulinoma. However, it may occur as a consequence of a paraneoplastic syndrome and has been described in hepatocellular carcinoma, lymphoma, hemangiosarcoma, oral cavity melanoma, hepatoma, gastric leiomyosarcoma and multiple myeloma [9] [10] [11]. The clinical signs commonly related to hypoglycemia are seizures, disorientation, paresis, weakness, tachycardia, among others. Generally, these neurological signs are observed when glycemia is less than $45 \mathrm{mg} / \mathrm{dL}$ [11] [12] [13]. The objective of this study is to report a case of hypoglycemia associated with gastric tumor in a dog.

\section{Case Report}

A German Shepherd Dog, $34 \mathrm{~kg}, 10$ years old, intact male, was taken to the Veterinary Hospital of the State University of Londrina (UEL, PR, Brazil) with a history of two episodes of generalized seizures in one day. He had been weak, ataxic and lethargic for 5 days. Physical examination showed tachypnea, muscle weakness, ataxia, pain in the lumbosacral region and in the hip and palpable mass in the cranial abdomen with the presence of pain on palpation.

Laboratory tests are present in Table 1, which revealed intense hypoglycemia. No alterations were observed in urinalysis. The patient also presented hypoinsulinemia $(0.01 \mathrm{UI} / \mathrm{mL})$ performed by the radioimmunoassay technique (reference values 5 - $25 \mathrm{UI} / \mathrm{mL}$ ). Abdominal ultrasound showed a large mass without defined delimitations, in the mesogastric topography, without any signs of metastasis in the pancreas, lymph nodes, liver and other abdominal organs. On radiographic examination, no metastasis were found in the lungs or mediastinum.

The emergency treatment consisted of ringer fluid therapy with sodium lactate, $50 \%$ bolus glucose followed by continuous infusion of $5 \%$ glucose and intravenous (IV) dexamethasone $(0.2 \mathrm{mg} / \mathrm{kg})$. After stabilization, the value of glycemia was $113 \mathrm{mg} / \mathrm{dL}$ and the patient went through exploratory celiotomy, when a pedunculated abdominal mass was observed in the wall of the stomach (serosa), in the region of the greater curvature and pyloric antrum, measuring 12 $\times 8,5 \times 5 \mathrm{~cm}$, which was removed with margin. At the inspection of the other abdominal organs, nonenodular lesions were observed and samples from other organs were not collected.

Due to suspected insulinoma, dexamethasone $(0.15 \mathrm{mg} / \mathrm{kg}$ every 12 hours IV), analgesia (tramadol, dipyrone), maropitant citrate and fluid therapy with glycophysiological solution were continued. The patient was discharged three days after surgery with a prescription of prednisone $(0.5 \mathrm{mg} / \mathrm{kg}$ every 12 hours, orally) as maintenance therapy for 14 days.

Macroscopic examination revealed a well-vascularized mass with an irregular surface, a dark red color with a yellowish focal area and firm consistency (Figure 1(a)). The cutting surface of the neoformation has fibrous appearance and areas of multifocal necrosis and calcification (Figure 1(b)). Microscopically, we observed a highly cellular, encapsulated neoformation composed of short and long 
Table 1. Results of laboratory tests performed in a 10-year-old, intact male German Shepherd Dog with Gastric Leiomyosarcoma.

\begin{tabular}{|c|c|c|}
\hline Total Blood Count & Results & Reference Values (Canine) \\
\hline Red Blood Cells & $5.13 / \mathrm{mm}^{3}$ & $5.5-8.5 / \mathrm{mm}^{3}$ \\
\hline Hemoglobin & $11.8 \mathrm{~g} / \mathrm{dL}$ & $12-18 \mathrm{~g} / \mathrm{dL}$ \\
\hline Hematocrit & $32.6 \%$ & $37 \%-55 \%$ \\
\hline VCM & $63.5 \mathrm{fL}$ & $60-77 \mathrm{fL}$ \\
\hline $\mathrm{HCM}$ & $23.0 \mathrm{pg}$ & $19-23 \mathrm{pg}$ \\
\hline $\mathrm{CHCM}$ & $36.2 \%$ & $32 \%-36 \%$ \\
\hline Platelets & $462.000 / \mathrm{mm}^{3}$ & $200-500 / \mathrm{mm}^{3}$ \\
\hline Total Proteins & $6.2 \mathrm{mg} / \mathrm{dL}$ & $6-8 \mathrm{mg} / \mathrm{dL}$ \\
\hline Leukocytes & $8.400 / \mathrm{mm}^{3}$ & $6.000-17.000 / \mathrm{mm}^{3}$ \\
\hline Rods & $168 / \mathrm{mm}^{3}$ & $0-300 / \mathrm{mm}^{3}$ \\
\hline Segmented & $7.392 / \mathrm{mm}^{3}$ & $3.000-11.500 / \mathrm{mm}^{3}$ \\
\hline Lymphocytes & $672 / \mathrm{mm}^{3}$ & $1.000-4.800 / \mathrm{mm}^{3}$ \\
\hline \multicolumn{3}{|l|}{ Serum Biochemistry } \\
\hline Glucose & $27 \mathrm{mg} / \mathrm{dL}$ & $70-110 \mathrm{mg} / \mathrm{dL}$ \\
\hline ALP & $21 \mathrm{U} / \mathrm{L}$ & $12-110 \mathrm{U} / \mathrm{L}$ \\
\hline ALT & $18 \mathrm{U} / \mathrm{L}$ & $17-87 \mathrm{U} / \mathrm{L}$ \\
\hline Albumin & $2.8 \mathrm{~g} / \mathrm{dL}$ & $2.1-4.3 \mathrm{~g} / \mathrm{dL}$ \\
\hline Triglycerides & $42 \mathrm{mg} / \mathrm{dL}$ & $80-150 \mathrm{mg} / \mathrm{dL}$ \\
\hline Cholesterol & $118 \mathrm{mg} / \mathrm{dL}$ & $135-270 \mathrm{mg} / \mathrm{dL}$ \\
\hline Phosphorus & $6.3 \mathrm{mg} / \mathrm{dL}$ & $2.6-6.2 \mathrm{mg} / \mathrm{dL}$ \\
\hline \multicolumn{3}{|l|}{ Eletrolytes } \\
\hline Sodium & $149.7 \mathrm{mmol} / \mathrm{L}$ & $141.1-152.3 \mathrm{mmol} / \mathrm{L}$ \\
\hline Potassium & $3.71 \mathrm{mmol} / \mathrm{L}$ & $4.37-5.65 \mathrm{mmol} / \mathrm{L}$ \\
\hline Chlorine & $115.2 \mathrm{mmol} / \mathrm{L}$ & $105-115 \mathrm{mmol} / \mathrm{L}$ \\
\hline Ionizable calcium & $4.75 \mathrm{mg} / \mathrm{dL}$ & $5.2-6.0 \mathrm{mg} / \mathrm{dL}$ \\
\hline
\end{tabular}

fusiform cell bundles paired with fibrillar cytoplasm, intensely eosinophilic, moderate pleomorphism, rare mitotic figures, and multifocal areas of necrosis and calcification (Figure 1(c)). The histopathological diagnosis was Well Differentiated Leiomyosarcoma. Immunohistochemical evaluation was performed for anti-alpha smooth muscle act in antibodies, DOG-1 and CD117 for the differential diagnosis of gastrointestinal stromal tumor (GIST), with strongly positive and diffuse labeling for the first and negative for the latter, confirming the diagnosis of leiomyosarcoma (Figure 1(d)).

The patient remained without clinical changes and without signs of metastasis at the ultrasound examination of the abdominal cavity until 27 months after the surgery. Unfortunately, the patient went through euthanasia due to chronic kidney disease and complications of degenerative joint disease. The patient's owner authorized the disclosure of the case for the purpose of scientific interest. 


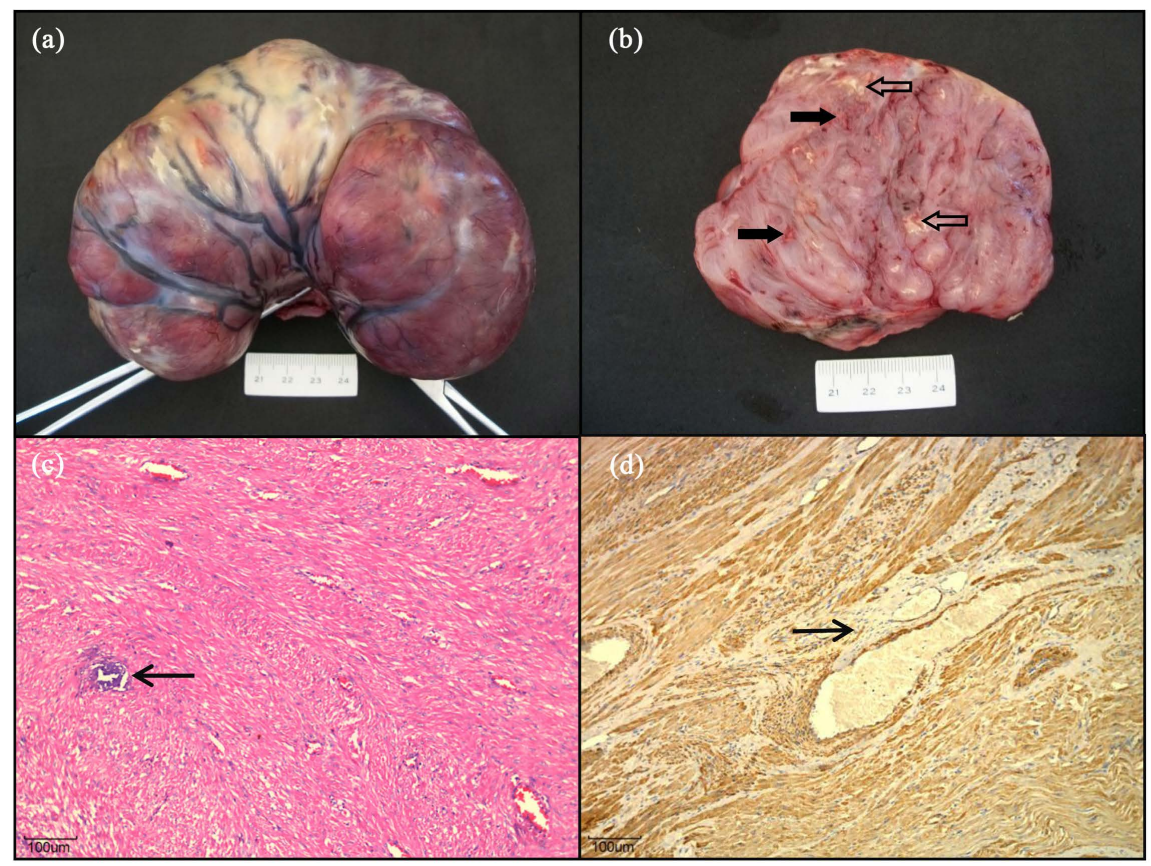

Figure 1. Gastric leiomyosarcoma in dog. (a) Neoformation of dark red color, with evident vascularization and focally extensive yellowish area. The region where the hemostatic clamps are located corresponds to the pedicle that connected the neoplasm to the stomach; (b) Cutting surface of the neoformation of fibrous aspect, compact, with areas of necrosis (full arrows) and calcification (empty arrows), multifocally; (c) Photomicroscopy. Dense, highly cellular neoformation, composed of spindle cells arranged in interlaced long bundles, with a focus of calcification (arrow). Hematoxylin and Eosin, 10x; (d) Strong and diffuse immunoblotting for smooth muscle alpha actin in neoplastic cells, negative in the adjacent stroma (arrow). Immunoperoxidase, DAB, 10×.

\section{Discussion}

The morphological distinction between leiomyoma, leiomyosarcoma and GIST is extremely difficult due to similar myogenic differentiation [14] [15], and it is therefore recommended to perform immunohistochemistry. The smooth muscle alpha-actin antibody has greater sensitivity and specificity for neoplasms derived from smooth muscle cells [3]. Strong and diffuse immunopositivity for smooth muscle alpha-actin antibody and negativity for DOG-1 and CD117 supported the diagnosis of leiomyosarcoma well-differentiated in the present case. One hypothesis for this antibody been positive is that some sarcomas arise from vascular tissue of the smooth muscle or myofibroblast, which are usually negative for other markers [3].

In addition, the gastrointestinal mesenchymal neoplasms in dogs, although slow growing, usually present with aggressive behavior and potentially metastatic, especially in the liver, mesenteric lymph nodes and peritoneum [6] [7]. When early clinical diagnosis followed by medical and surgical treatment can be done, the risk of relapse decreases, increasing the patient survival rate [6] [7], as observed. In the present case, despite being a large malignant tumor, metastases were not observed, which might be related to its well-differentiated character 
[16], to the slow metastatic index in dogs' gastrointestinal leiomyosarcoma [7] or to the fact that metastatic behavior is more common in the neoplasms originated from the epithelium when considering the gastric neoplasms [3].

The main clinical manifestations of gastrointestinal tumors are emesis, melena, weight loss and anorexia, due to obstructive conditions, stenosis and ulceration usually located in the gastric body and pylorus [2]. The last ones were not observed in the case described because of the pediculated aspect of the mass. The gastrointestinal transit was not altered and mucosa ulceration was not observed as well. Even though leiomyosarcoma has predisposition to the jejunum and cecum regions, any portion of the tract can be affected, from the esophagus to the rectum [4]. In some cases, the first clinical signs presented by oncology patients are signs of paraneoplastic syndrome, not clinically suspected [17], such as hypoglycemia, which is also described by reference [4] as a clinical sign depending on the primary site of the tumor or secondary metastatic sites.

Signs of weakness, muscle atrophy, ataxia, and seizures were due to severe and chronic hypoglycemia. In addition to these signs, patients may present with behavioral disorders, stupor and coma related to neuroglycopenia, since the brain consumes about $25 \%$ of the body's glucose despite constituting only $2 \%$ of the body surface [18] [19]. According to reference [9] the most common clinical sign that the authors observed in four other dogs with smooth muscle tumors was seizure, as well observed in this present case, followed by polyuria, polydipsia, ataxia, collapse and hemoperitoneum.

Gastrointestinal leiomyosarcoma has slow growth rate [7], suggesting that the tumor of the dog in question was developing in a chronic way, although the clinical signs reported during the anamnesis presented with evolution of 5 days. Clinical signs were reported to be present for 1 day in 3 of 6 dogs, 10 days in 1 of 6 dogs and 1 month in 2 from 6 dogs presented with smooth muscle tumors [9], corroborating with the acute manifestation of the present case. Often the signs of hypoglycemia appear slowly due to the secretion of hyperglycemic hormones (adrenaline, glucocorticoids) in response to severe hypoglycemia. In addition, early signs of hypoglycemia such as weakness, muscle tremors, and exercise intolerance may also be confounded with other neuromuscular changes as well as osteoarticular diseases [20], as observed in this patient.

Hypoglycemia represents an uncommon paraneoplastic syndrome, but may be present in several tumor processes, especially insulinoma, plasmacytoma, lymphoma, leiomyosarcoma, oral melanoma, hemangiosarcoma, adenocarcinoma of the salivary glands and more rarely in mammary carcinomas [21]. The occurrence of hypoglycemia secondary to extra pancreatic tumors is due to the secretion of insulin-like growth factors I and II (IGF-1 and IGF-2), decreased hepatic glycogenolysis or gluconeogenesis, increased sensitivity of insulin receptors to exogenous insulin, and increased use of glucose by tumors [22]. Hypoglycemia secondary to insulinoma is related to the secretion of elevated insulin levels [11] [23]. 
Hypoglycemia associated with intra-abdominal leiomyosarcoma may be due to excessive consumption of glucose by the tumor, decreased hepatic gluconeogenesis secondary to neoplasia or IGF-2 secretion by the tumor. This mechanism reduces blood glucose concentrations, increasing its use by normal cells [5] [9] [22] [23] [24] [25]. After surgical resection, glycemia normalization and resolution of clinical signs occurred, however, it was not possible to determine the mechanism of hypoglycemia development, since hyperinsulinemia was not present and IGF-I or IGF-II were not measured. Hypoinsulinemia associated with histopathological and immunohistochemical findings, as well as the insulin: glucose ratio $<0.3$ discarded insulinoma, confirming that described by other authors [11] [23].

\section{Conclusion}

Due to the rare occurrence of this neoplasm in stomach regions, histopathological analysis was essential for the conclusion of the diagnosis of gastric leiomyosarcoma. Hypoglycemia associated with gastric neoplasia reinforces the need for diagnostic investigation to differentiate the causes of neoplastic hypoglycemia, since in the clinic routine often the only differential included is insulinoma. The histopathological and immunohistochemical studies make this differentiation possible.

\section{Conflicts of Interest}

The authors declare no conflicts of interest regarding the publication of this paper.

\section{References}

[1] Swann, H.M. and Holt, D.E. (2002) Canine Gastric Adenocarcinoma and Leiomyosarcoma: A Retrospective Study of 21 Cases (1986-1999) and Literature Review. Journal American Animal Hospital Association, 38, 157-164. https://doi.org/10.5326/0380157

[2] Leibman, N.F., Larson, V.S. and Ogilvie, G.K. (2005) Oncology Diseases Gastrointestinal Tract. In: Tams, T.R., Ed., Handbook of Small Animal Gastroenterology, 2nd Edition, Saunders/Elsevier, St. Louis, 385-392.

[3] Araujo, D.C.C.A., Santos, I.O.V., Silva, M.A., Pessoa, C.C.V., Carvalho, J.R.G., Lopes, N.L. and Fernandes, J.I. (2016) Sarcoma Gastrointestinal em cão Relato de Caso. Revista Brasileira de Medicina Veterinária, 38, 178-182.

[4] Prado, L.O.C., Franco, G.G., Legatti, E., Ranzani, J.J.T., Quitzan, J.G., Siqueira, E.G.M., Souza, J.A.L., Minto, B.W. and Brandão, C.V.S. (2017) Leiomiossarcoma gástrico associado a hérnia de hiato em cão da raça Sharpei: Relato de Caso. Arquivo Brasileiro de Medicina Veterinária e Zootecnia, 69, 111-116. https://doi.org/10.1590/1678-4162-8900

[5] Cohen, M., Post, G.S. and Wright, J.C. (2003) Gastrointestinal Leiomyosarcoma in 14 Dogs. Journal of Veterinary Internal Medicine, 17, 107-110. https://doi.org/10.1111/j.1939-1676.2003.tb01331.x

[6] Kapatkin, A.S., Mullen, H.S., Mathiesen, D.T. and Patnaik, A.K. (1992) Leiomyo- 
sarcoma in Dogs: 44 Cases (1983-1988). Journal of the American Veterinary Medical Association, 201, 1077-1079.

[7] Selting, K.A. (2007) Cancer of the Gastrointestinal Tract. In: Withrow, S.J. and Macewen, E.G., Eds., Small Animal Clinical Oncology, 4th Edition, Saunders/Elsevier, St. Louis, 491-493.

[8] Frgelecová, L., Škorič, M., Fictum, P. and Husník, R. (2013) Canine Gastrointestinal Tract Tumours: A Retrospective Study of 74 Cases. Journal Acta Veterinaria Brno, 82, 387-392. https://doi.org/10.2754/avb201382040387

[9] Beaudry, D., Knapp, D.W., Montgomery, T., Sandusky, G.S., Morrison, W.B. and Nelson, R.W. (1995) Hypoglycemia in Four Dogs with Smooth Muscle Tumors. Journal Veterinary Internal Medicine, 9, 415-418. https://doi.org/10.1111/j.1939-1676.1995.tb03302.x

[10] Sakai, M., Asano, K., Nakata, M., Takahashi, T., Koie, H., Yamaya, Y., Watari, T., Shibuya, H., Sato, T., Tokuriki, M. and Hasegawa, A. (2006) Diabetes Mellitus after Resection of Hepatocellular Carcinoma with Hypoglycemia in a Dog. The Journal of Veterinary Medical Science, 68, 765-767. https://doi.org/10.1292/jvms.68.765

[11] Mangieri, J. (2009) Síndromes paraneoplásicas. In: Daleck, et al., Eds., Oncologia em cães e gatos, ROCA, São Paulo, 238-249.

[12] Ogilvie, G.K. (2004) Síndromes paraneoplásicas. In: Ettinger, S.J. and Feldman, E.C., Eds., Tratado de Medicina Veterinária Interna, 5th Edition, Guanabara-Koogan, Rio de Janeiro, 529-537.

[13] Battaglia, L., Petterino, C., Zappuli, V. and Castagnaro, M. (2005) Hypoglycaemia as a Paraneoplastic Syndrome Associated with Renal Adenocarcinoma in a Dog. Veterinary Research Communications, 29, 671-675.

https://doi.org/10.1007/s11259-005-3305-x

[14] Frost, D., Lasota, J. and Miettinen, M. (2003) Gastrointestinal Stromal Tumors and Leiomyomas in the Dog: A Histopathologic, Immunohistochemical, and Molecular Genetic Study of 50 Cases. Veterinary Pathology, 40, 42-54.

https://doi.org/10.1354/vp.40-1-42

[15] Dailey, D.D., Ehrhart, E.J., Durval, D.L., Bass, T. and Powers, B.E. (2015) DOG1 Is a Sensitive and Specific Immunohistochemical Marker for Diagnosis of Canine Gastrointestinal Stromal Tumors. Journal of Veterinary Diagnostic Investigation, 27, 3268-277. https://doi.org/10.1177/1040638715578878

[16] Hayes, S., Yuzbasiyan-Gurkan, V., Gregory-Bryson, E. and Kiupel, M. (2013) Classification of Canine Nonangiogenic, Nonlymphogenic, Gastrointestinal Sarcomas Based on Microscopic, Immunohistochemical, and Molecular Characteristics. Veterinary Pathology, 50, 779-788. https://doi.org/10.1177/0300985813478211

[17] Oliveira, K.M., Horta, R.S., Silva, C.M.O. and Lavor, M.S.L. (2013) Principais síndromes paraneoplásicas em cães e gatos. Enciclopédia Biosfera, 9, 2073-2088.

[18] Shimada, A., Morita, T., Ikeda, N., Torii, S. and Haruna, A. (2000) Hypoglycaemic Brain Lesions in a Dog with Insulinoma. Journal of Comparative Pathology, 122, 67-71. https://doi.org/10.1053/jcpa.1999.0342

[19] Peters, A., Schweigwer, U., Pellerin, L., Hubold, C., Oltmanns, K.M., Conrad, M., Schltes, B., Born, J. and Fehm, H.L. (2004) The Selfish Brain: Competition for Energy Resources. Neuroscience \& Biobehavioral Reviews, 28, 143-180. https://doi.org/10.1016/j.neubiorev.2004.03.002

[20] Schoeman, J.P. (2015) Avaliação da Hipoglicemia. In: Mooney, C., Peterson, M. and Fagliari, J.J., Eds., Manual de Endocrinologia de Cães e Gatos, 4th Edition, ROCA, Rio de Janeiro, 304-310. 
[21] Bergman, P.J. (2012) Paraneoplastic Syndromes. In: Withrow, S., Vail, D. and Page, R., Eds., Withrow and MacEwen's, Small Animal Clinical Oncology, 5th Edition, Saunders/Elsevier, Amsterdam, 768.

[22] Finotello, R., Ressel, L., Arvigo, M., Baroni, G., Marchetti, V., Romanelli, G., Burrow, R., Mignacca, D. and Blackwood, L. (2016) Canine Pancreatic Islet Cell Tumours Secreting Insulin-Like Growth Factor Type 2: A Rare Entity. Veterinary and Comparative Oncology, 14, 170-180. https://doi.org/10.1111/vco.12085

[23] Bailey, D.B. and Page, R.L. (2012) Tumors of the Endocrine System. In: Withrow, S., Vail, D. and Page, R., Eds., Withrow and MacEwen's, Small Animal Clinical Oncology, 5th Edition, Saunders/Elsevier, Amsterdam, 768.

[24] Bagley, R.S., Levy, J.K. and Malarkey, D.E. (1996) Hypoglycemia Associated with Intra-Abdominal Leiomyoma and Leiomyosarcoma in Six Dogs. Journal of the American Veterinary Medical Association, 208, 69-71.

[25] Bellah, J.R. and Ginn, P.E. (1996) Gastric Leiomyosarcoma Associated with Hypoglycemia in a Dog. Journal of the American Animal Hospital Association, 32, 283-286. https://doi.org/10.5326/15473317-32-4-283 